\title{
Polimeraz zincir reaksiyonu ile tanısı konulan ve komplikasyonla seyreden bir pnömokok menenjiti olgusu
}

\section{A case of pneumococcal meningitis with complication diagnosed with polymerase chain reaction}

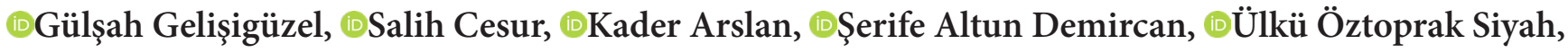 \\ 몬 Sami Kınıklı \\ Sağlık Bilimleri Üniversitesi, Ankara Egitim ve Arastırma Hastanesi, Enfeksiyon Hastalıkları ve Klinik Mikrobiyoloji Kliniği, Ankara, Türkiye
}

Cite this article as / Bu makaleye atıf için: Gelişigüzel G, Cesur S, Arslan K, Altun Demircan Ş, Öztoprak Siyah Ü, Kınıklı S. Polimeraz zincir reaksiyonu ile tanısı konulan ve komplikasyonla seyreden bir pnömokok menenjiti olgusu. J Med Palliat Care 2021; 2(2): 58-61.

\begin{abstract}
ÖZ
Bakteriyel menenjitlerin erken tanısı ve tedavisinde kültür sonuçları en erken $24-48$ saatte çıktığından ötürü, klinik bulgularla birlikte beyin omurilik sıvısı (BOS)'nda hücre sayımı, BOS’un biyokimyasal özellikleri ve BOS’un Gram boyama ile incelenmesi büyük önem taşımaktadır. Özellikle menenjitlerin infeksiyon acili olması nedeniyle kültür için BOS ve kan örneği alınmadan ampirik tedavinin erken başlandığı veya hastaların önceden antibiyotik tedavisi aldığı durumlarda kültürde etkenin saptanma olasılığı azalır veya ortadan kalkar. Bu gibi durumlarda BOS'un Gram boyaması, BOS'da bakteri antijenlerinin araştırılması yanı sıra son yıllarda polieraz zincir reaksiyonu ile de bakteri DNA'sı araştırılarak da tanıya gidilebilmektedir. Burada, menenjit ön tanısıyla BOS örneği alınmadan seftriakson tedavisi başlanan bu nedenle kültürde etkenin saptanmadığı, ancak; multipleks PZR yöntemiyle BOS’da Streptococcus pneumoniae pozitif saptanan 46 yaşında bir kadın hasta sunularak literatür gözden geçirildi. Olguda uygun antimikrobiyal tedaviye rağmen, pnömokok menenjiti komplikasyonu olarak superior sagittal sinüs ve bilateral transverslerde yaygın serebral trombüs gelişti.
\end{abstract}

Anahtar Kelimeler: Menenjit, bakteriyel etkenler, Streptococcus pneumoniae, multipleks-PZR

\begin{abstract}
Culture results that allow diagnosis and treatment of bacterial meningitis are at the earliest 24-48 hours. Therefore, cell count in cerebrospinal fluid (CSF), biochemical properties of CSF and examination of CSF by Gram staining are of great importance for early diagnosis together with clinical findings. Since the meningitis is an emergency in terms of infection, especially in cases where the empirical treatment is started early without CSF and blood sample collection, or if patients have already received antibiotic treatment, the probability of detection of the agent in culture is reduced or disappeared. In such cases, diagnosis can be made by gram staining of CSF, investigation of bacterial antigens in CSF, and investigation of bacterial DNA by polymerase chain reaction. In this study, a 46-year-old female patient was presented and the literature was reviewed. In the case, ceftriaxone treatment was started without a CSF sample due to a preliminary diagnosis of meningitis. Therefore, no agent was detected in culture, but Streptococcus pneumoniae was found to be positive in CSF by multiplex PCR. Althoug apropriate antimicrobial treatment, the superior sagittal sinus and diffuse cerebral thrombus in bilateral transverses developed as a complication of pneumococcal meningitis.
\end{abstract}

Keywords: Meningitis, bacterial agents, Streptococcus pneumoniae, multiplex-PCR

\section{Gíriș}

Santral sinir sistemi (SSS) enfeksiyonlar1; menenjit, ensefalit, meningoensefalit, beyin apsesi, subdural ampiyem, epidural apse vb. farklı klinik tabloları içerir. Menenjit, çeşitli mikroorganizmaların neden olduğu meninkslerin inflamasyonu olup, subaraknoid mesafede

gelişen pia-araknoidittir. Menenjitler infeksiyon acilleri içerisinde yer alır. Menenjitlerde tanı ve tedavide gecikme ciddi mortalite ve morbiditeye neden olabilir, bu nedenle menejitlerin erken tanı ve tedavisi gerekir. Akut pürülan menenjitler genellikle bakteriyel, akut 
aseptik menenjitler ise genellikle viral etkenlere bağlı olarak gelişir. Menenjitlerin etiyolojik dağılımı, yaş, coğrafi farklılıklar, altta yatan hastalıklara bağlı olarak farklılıklar gösterir. Akut bakteriyel menenjit olgularının \%80-85 kadarından Streptococcus pneumoniae (S. pneumoniae), Neisseria meningitidis (N. meningitidis) ve Haemophilus influenzae ( $H$. influenzae) sorumlu olmasına karşın, belirli yaş gruplarında ve bazı altta yatan hastalık durumlarında (örneğin kafa kaidesi kırığı olanlarda pnömokok menejitinin sık görülmesi, gebe ve immunsüpresif hastalarda Listeria monocytogenes menenjitinin sık görülmesi gibi) görülme sıklıkları değiş̧ebilir $(1,2)$. Çoğu kez etiyoloji saptanamayan aseptik menenjit olgularının büyük kısmından (\%80-95) polio dışı enterovirusların sorumlu olduğu bildirilmiştir. Günümüzde bakteriyel ve viral (aseptik) menenjitlerin tanısinda polimeraz zincir reaksiyonu (PZR) yaygin olarak kullanılmaktadır $(1,3,4)$. Bu yazıda, daha önce tek doz tedavi başlanması nedeniyle BOS kültüründe üreme olmayan, ancak; BOS'da real time yöntemiyle $S$. pneumoniae menenjiti tanısı konulan ve komplikasyon olarak venöz trombüs gelișen bir olgu sunuldu.

\section{OLGU}

Kırk altı yaşında kadın hasta bir gün önce başlayan baş ağrısı, kusma ve sonrasında ortaya çıkan bilinç bulanıklığı şikayetleri ile hastaneye başvurdu. Anamnezinden bir haftadır devam eden gribal semptomları, ateş, öksürük ve balgam çıkarma yakınmalarının olduğu öğrenildi. Acil servisteki fizik muaynesinde; ateș: $36,7^{\circ} \mathrm{C}$, TA: $120 / 70$ nabız: 92/dk, $\mathrm{O}_{2}$ saturasyonu: \%96 olarak belirlendi. Genel durumu orta, bilinci konfüze, oryantasyon ve kooperasyonu yoktu. Ense sertliği, Kernig ve Brudzinski bulguları negatif olarak saptandı, diğer sistem muayeneleri de normaldi.

Laboratuvar incelemesinde; lökosit sayısı: $21.000 / \mathrm{mm}^{3}$, periferik yaymada \%92 parçalı, \%2,6 lenfosit vardı. Sedimentasyon hızı $8 \mathrm{~mm} / \mathrm{saat}$, CRP:19,4 mg/L (normali: 0-5 mg/L), diğer biyokimyasal değerleri normaldi. Hastaya acil serviste menenjit ön tanısiyla $2 \times 2$ gr seftriakson intravenöz (I.V) tedavisi başlanmıștı. Hastaya lomber ponksiyon yapıldı. Beyin omurilik sivisı incelemesinde bos basınc1 artmış, hücre sayısı: $6400 / \mathrm{mm}^{3}$ (\%80 polimorfonükleer lökosit) yeni eritrosit $1120 / \mathrm{mm}^{3}$, BOS glukozu: $76 \mathrm{mg} / \mathrm{dL}$ (eş zamanlı kan şekeri: $110 \mathrm{mg} / \mathrm{dL}$ ) protein $2770 \mathrm{mg} / \mathrm{L}$, klor $112 \mathrm{mmol} / \mathrm{L}$ idi. Gram boyamada mikroorganizma görülmedi. Hasta menenjit tanısıya enfeksiyon hastalıkları servisine yatırıldı. Seftriaskon $2 \times 2$ gr IV tedavisine asiklovir $3 \times 750 \mathrm{mg}$ IV eklendi. BOS ve kan kültürlerinde üreme olmadi. BOS multipleks polimeraz zincir reaksiyonu (PZR) sonucu S. pneumoniae olarak rapor edildi, bunun üzerine asiklovir tedavisi kesildi, seftriakson tedavisine devam edildi. Tedaviden yaklaşık 48 saat sonra bilinci açıldı genel durumu düzeldi.
Tedavisinin 3. gününde sağ kol ve bacağında güçsüzlük his kaybı meydana geldi. Hastanın beyin bilgisayarlı tomografi (BT) incelemesinde patoloji saptanmadi, Nöroloji tarafından hastaya $300 \mathrm{mg}$ asetilsalisilik asit başlandı, difüzyon manyetik rezonans görüntüleme (MRG) çekilmesi önerildi. Difüzyon MRG'de 'pakimeningeal ve leptomeningeal menenjit lehine yaygin kontrastlanmalara ek olarak superior sagittal sinüste ve transvers sinüslerde olmak üzere dural venöz trombozis' rapor edildi. Nöroloji tarafından yeniden değerendirilen hastaya trombüs tedavisi için enoksaparin sodyum subkutan yolla $2 \times 0,6 \mathrm{~mL}$ başland, aspirin tedavisi kesildi. Çekilen MR venografide 'superior sagittal sinüs ve bilateral transverslerde yaygin serebral trombüs' izlendi. Takiplerinde hastanın sağ bacağında güçsüzlüğü geriledi. Sağ elinde minimal güçsüzlük devam etmekteydi, ateşi olmadı. Antibiyoterapisi 14 güne tamamlandı. Hasta trombüs tedavisi açısından nöroloji servisine devredildi.

\section{TARTIŞMA}

Bakteriyel menenjitlerde hızlı tanı ve erken tedavi başlanması klinik sonuçlarda olumlu etkiye, mortalite ve morbiditede azalmaya neden olur. Son yllarda bakteriyel menenjitlerin erken tanısında moleküler yöntemler de yaygın olarakkullanılmaktadır $(4,7)$.Sunduğumuzolguda, BOS kültürü alınmadan önce menenjite yönelik olarak seftriakson tedavisi başlanması nedeniyle kültürde üreme olmadı. BOS'un Gram boyamasinda etken saptanmadı. BOS'da multipleks PZR sonucunda S. pneumoniae pozitif olarak rapor edilmesi üzerine seftriakson tedavisi 14 gün süreyle uyguland. Albuquerque ve ark. (4) bakteriyel menenjit (S. pneumoniae, $N$. menengitidis, $H$. influenzae ve herhangi bir bakteriyel etken) etkenlerine yönelik geliştirdikleri multipleks PZR kiti ile yaptıkları çalışmada, 447 BOS örneğinin 40’ında (27'si kültür pozitif, 13'ü kültür negatif) multipleks PZR testini pozitif saptamışlardır. Yazarlar, özellikle antibiyotik ntedavisi alan hastalarda bile testin bakteriyel menenjit etkenini hızlı ve doğru olarak saptadığını, klinik tanı ve epidemiyolojik önlemleri iyileștirdiğini bildirmișlerdir (4). PZR gibi moleküler yöntemlerin bakteriyel menenjite yönelik erken antibiyotik tedavi başlanan, tedavi öncesi kültür için örnek alınmadığından tedavi başlandıktan sonra alınan kültürde üreme saptanmayan olgularda pozitif sonuç vermesi avantajıdır (5). PZR yönteminin kültürden daha önce sonuçlanması da bir diğer avantajıdır (6).

Seth ve ark. (7) 125 BOS örneğinde multipleks PZR yöntemiyle Gram boyama, kültür ve lateks aglütinasyon testinin duyarlılık ve özgüllüklerini araștırmıșlardır. Çalışmada toplam 39 olguda $(\% 31,2)$ klinik ve BOS'nın biyokimyasal analizine dayanarak akut bakteriyel menenjit tanısı konmuştur. Test edilen üç 
mikroorganizma (S. pneumoniae, H. influenzae tip B ve $N$. meneingitidis) için sadece 10 olguda (10/39) pozitiflik saptanmıştır. Multipleks PZR yöntemi S. pneumoniae ve $H$. influenzae tip b'nin her bir ilave izolatını daha tespit edebilmiştir. Altın standart olarak multiplex PZR ile karşılaştırıldığında, kültür ve lateks aglütinasyon testleri aynı duyarlılığa (\%80) ve özgüllüğe (\%100) sahipken, Gram boyamanın düşük duyarlılık (\%40), yüksek özgüllüğe (\%95) sahip olduğu saptanmıştır. $S$. pneumoniae ve $H$. influenzae tip B için tespit oranları multipleks PZR'de daha yüksek belirlenmiştir. Sonuç olarak, multipleks PZR yönteminin kültür veya antijen testinden daha duyarlı olduğu ve patojenin doğru ve hızlı tanımlanmasını önemli ölçüde arttırdığı bildirilmiştir.

Pediatrik bakteriyel menenjit olgularında yapılan bir çalışmada toplam 2025 BOS örneğinde PZR yöntemiyle S. pneumoniae DNA’sı saptanmasının kültür yöntemiyle karşılaştırılması yapılmıştır. Çalışmada, PZR yöntemiyle S. pneumoniae DNA’sı saptanmasının kültür ile karşılaştırılmasında; PZR yönteminin \%100 duyarlılığa ve \%98 özgüllüğe sahip olduğu belirlenmiştir. Yirmi sekiz kültür negatif/PZR pozitif olgunun 25 (\%89)'i olası menenjit olarak değerlendirilirken, sadece 3 (\%11)'ünde yanlış pozitif sonuçdan şüphelenilmiştir. Sonuç olarak, S. pneumoniae için BOS örneklerde PZR testinin kültürle karşılaştırıldığında; daha yüksek oranda duyarlılık ve spesifiteye sahip olduğu saptanmıștır. Özellikle PZR testinin antimikrobiyal tedavi öncesinde BOS örneklemesi yapılmayan, kültür negatif olguları tespit etmekte yararlı olduğu bildirilmiştir (8). Sunduğumuz olguda da ampirik tedavi öncesinde BOS örneği alınmaması, BOS kültürünün tedavi başlandıktan sonra alınması nedeniyle kültürde üreme olmazken, BOS'da multipleks PZR yöntemi ile S. pneumoniae tespit edildi. Başka bir çalışmada, klinik ve BOS bulguları ile menenjit tanısı konan ancak kültür negatif saptanan 40 BOS örneğinde real time PZR yöntemiyle 36 örnekte (\%90) S. pneumoniae saptanırken, $H$. influenzae veya $N$. meningitidis saptanmamıştır. Dört (\%10) örnek real-time PZR yöntemiyle negatif olarak belirlenmiştir (9).

Olgumuzda tedaviye ragmen $S$. pneumoniae menenjiti komplikasyonu olarak venöz trombüs gelişti. Pnömokok menenjitlerinde bildirilen başlıca komplikasyonlar; beyin ödemi, hidrosefali, arteriyel ve venöz serebrovasküler komplikasyonlar, intrakraniyal kanama, beyinde infarktus, myelit, işitme kaybıdır $(10,11)$.

Kastenbauer ve ark. (10) 87 erişkin pnömokok menenjiti olgusunun incelendiği bir çalışmada; menenjit ile ilişkili intrakraniyal komplikasyonlar \%74,7, sistemik komplikasyonlar \%37,9 olarak saptanmıştır. Çalışmada diffüz beyin ödemi $\% 28,7$, hidrosefali $\% 16$, arteriyel serebrovasküler komplikasyonlar $\% 21,8$ ve venöz serebrovasküler komplikasyon \%9,2 olarak belirlenmiştir.
Ayrıca, olguların \%9,2'sinde spontan intrakraniyal kanama gelişmiş; olguların \%2,3'ünde miyelit, \%19,5'inde işitme kaybı saptanmıştır. Hastane içi ölüm oranı \%24,1 olarak saptanmıştır. Kötü sonuçla ilişkili faktörler; Glasgow skorunun $\leq 4$ olması, başvurudaki fokal nörolojik defisitler, düşük BOS lökosit sayısı, pnömoni, bakteriyemi ve menenjitle ilişkili kafa içi ve sistemik komplikasyonlar olarak belirlenmiştir. Düşük BOS lökosit sayısı ayrıca menenjitle ilişkili kafa içi komplikasyonların gelişimi ile ilişkili saptanmıştır. Sunduğumuz olgusa BOS lökosit sayısı $\left(6400 / \mathrm{mm}^{3}\right)$ düşük değildi.

Altmış yaş ve üzeri pnömokok menenjiti olan hastalarda mortalite oranı daha yüksek saptanmıştır. Ölüm nedenleri; yaşlı hastalarda sistemik komplikasyonlar, genç hastalarda ise serebral komplikasyonlara bağlı olarak gelişmiştir.

Pnömokokal menenjitli çocuk hastaların incelendiği bir çalışmada; pnömokokal menenjit hastalarının 316 'sında mortalite oranı \%9,5 iken, olguların \%23,1'i komplikasyon (apse, koma, hemodinamik yetmezlik, serebral tromboflebit veya sağırlık) bildirilmiştir. Toplamda 108 (\%34) çocuk hastada risk faktörleri saptanmış, bu risk faktörleri; $70(\% 22,8)$ olguda beyin omurilik sıvısı kaçağı veya fistül şeklinde anatomik bozukluk, $55(\% 17,9)$ olguda ise primer veya edinsel yetmezlik olarak belirlenmiştir (12).

Pnömokok menenjitinden ölen 16 hastanın beyin dokusunun incelendiği bir çalışmada, hastaların \%38'inde fokal nörolojik defisit saptanmıştır. Otopside 9 (\%56) serebral infarktüslü hastada serebral infarktüsü olmayan hastalara göre arteriyel trombozis oranı daha fazla oranda saptanmıştır (13).

Kortikal ven trombozu gelişen hastaların incelendiği bir çalışmada, kortikal ven trombozu sıklığı menenjitli hastalarda 790 olgunun \%1'inde bildirilmiştir (14).

Sunduğumuz olguda tanının BOS'da PZR pozitifliği ile konması ve tedavide gecikme olmamasına rağmen venöz trombüs komplikasyonu gelişmesi yönüyle de ilginçtir.

\section{SONUÇ}

Sunduğumuz olguda olduğu gibi BOS kültürü alınmadan ampirik olarak bakteriyel menenjit tedavisi başlanan hastalarda moleküler tanı yöntemleri ile bakteriyel menenjit etkenleri araştırılmalı ve hastalar menenjit komplikasyonları açısından yakından izlenmelidir.

\section{ETIKK BEYANLAR}

Aydınlatılmış Onam: Bu çalışmaya katılan hasta(lar) dan yazılı onam alınmıştır.

Hakem Değerlendirme Süreci: Harici çift kör hakem değerlendirmesi. 
Çıkar Çatışması Durumu: Yazarlar bu çalışmada herhangi bir çıkara dayalı ilişki olmadı̆̆ını beyan etmişlerdir.

Finansal Destek: Yazarlar bu çalışmada finansal destek almadıklarını beyan etmişlerdir.

Yazar Katkıları: Yazarların tümü; makalenin tasarımına, yürütülmesine, analizine katıldığını ve son sürümünü onayladıklarını beyan etmişlerdir.

\section{KAYNAKLAR}

1. Akkaya O, Güvenç Hİ, Güzelant A, et al. Menenjit etkenlerinin real-time PCR yöntemiyle araştırılması. Türk Mikrobiyol Cem Derg 2017; 47: 131-7.

2. Parlak M. Akut bakteriyel menenjitler. Toplumdan edinilmiş enfeksiyonlara pratik yaklaşımlar Sempozyum Dizisi, İ.Ủ. Cerrahpaşa Tıp Fakültesi yayınları 2008; 61: 151-64.

3. Jarrin I, Sellier P, Lopes A, et al. Etiologies and management of aseptic meningitis in patients admitted to an internal medicine department. Medicine (Baltimore) 2016; 95: e2372

4. Albuquerque RC, Moreno ACR, Dos Santos SR, Ragazzi SLB, Martinez MB. Multiplex-PCR for diagnosis of bacterial meningitis. Braz J Microbiol 2019; 50: 435-43.

5. Jing-Zi P, Zheng-Xin H, Wei-Jun C, Yong-Qiang J. Detection of bacterial meningitis pathogens by PCR-Mass spectrometry in cerebrospinal fluid. Clin Lab 2018; 64: 1013-9.

6. Nour M, Alaidarous A. Clinical usefulness and accuracy of polymerase chain reaction in the detection of bacterial meningitis agents in pediatric cerebrospinal fluid. Curr Res Transl Med 2018; 66: $15-8$

7. Seth R, Murthy PSR, Sistla S, Subramanian M, Tamilarasu K. Rapid and accurate diagnosis of acute pyogenic meningitis due to Streptococcus pneumoniae, Haemophilus influenzae Type b and Neisseria meningitidis Using A Multiplex PCR Assay. J Clin Diagn Res 2017; 11: FC01-4.

8. Alqayoudhi A, Nielsen M, O'Sullivan N, et al. Clinical utility of polymerase chain reaction testing for Streptococcus pneumoniae in pediatric cerebrospinal fluid samples: a diagnostic accuracy study of more than 2000 samples from 2004 to 2015. Pediatr Infect Dis J 2017; 36: 833-6.

9. Khater WS, Elabd SH. Identification of common bacterial pathogens causing meningitis in culture-negative cerebrospinal fluid samples using real-time polymerase chain reaction. Int J Microbiol 2016; 2016: 4197187.

10. Kastenbauer S, Pfister HW. Pneumococcal meningitis in adults: spectrum of complications and prognostic factors in a series of 87 cases. Brain 2003; 126: 1015-25.

11.Ilgar T, Özel Ö, Hatipoğlu ÇA, et al. Kafa kaidesi kırığına bağlı pnömokok menenjiti sekeli olarak gelişen serebral enfarktüs olgusu. Turk J Clin Lab 2017; 8: 217-20.

12. Hénaff F, Levy C, Cohen R, et al. Risk factors in children older than 5 years with Pneumococcal meningitis: data from a national network. Pediatr Infect Dis J 2017; 36: 457-61.

13. Vergouwen MD, Schut ES, Troost D, van de Beek D. Diffuse cerebral intravascular coagulation and cerebral infarction in pneumococcal meningitis. Neurocrit Care 2010; 13: 217-27.

14.DiNubile MJ, Boom WH, Southwick FS. Septic cortical thrombophlebitis. J Infect Dis 1990; 161: 1216-20. 